\title{
Effect of Ivermectin on semen parameters and levels of Alanine aminotransferase (ALT) and Aspartate aminotransferase (AST) enzymes in seminal plasma of Iraqi Awassi rams
}

Ali. J. Ali

Coll. of Vet. Med.-Univ. of Mosul

email:alijaddan@yahoo.com

\begin{abstract}
The objective of this study was to evaluation the effect of Ivermectin on semen quality and estimation of alanine aminotransferase (ALT), and aspartate aminotransferase (AST) in seminal plasma. Six mature Awassi rams aged 2-3 years and weighing 38-42 Kg were used in this study. Semen collection was done weekly for five weeks from the same ram. The first two collection was considers as training for the animal and discarded, the second two collection were considers for control group. After administration of the drug (Ivermectin), semen samples were collected from the Awassi ram 1, 7,14 days. The parameter studies were included semen volume, percentage motility of sperm, sperm concentration, live sperm, and morphology percentage. Samples of seminal plasma were analyzed for the estimation of alanine aminotransferase (ALT), aspartate aminotransferase (AST). Results of this study indicate that Ivermectin leads to significant $(\mathrm{P}<0.05)$ decreased in semen parameters after first semen collection. Reaction time significantly higher $(\mathrm{P}<0.05)$ in the treated group after 1 days of injection. Alanine aminotransferase ALT, Aspartate aminotransferase AST show no significant differences in activities in seminal plasma during study. In conclusion: it is preferable to use the animals for the purpose of reproduction only after at least 7 days after Ivermectin injection due to it harmful effect on semen quality.
\end{abstract}

Key words: Ivermectin, AST, ALT, Semen.

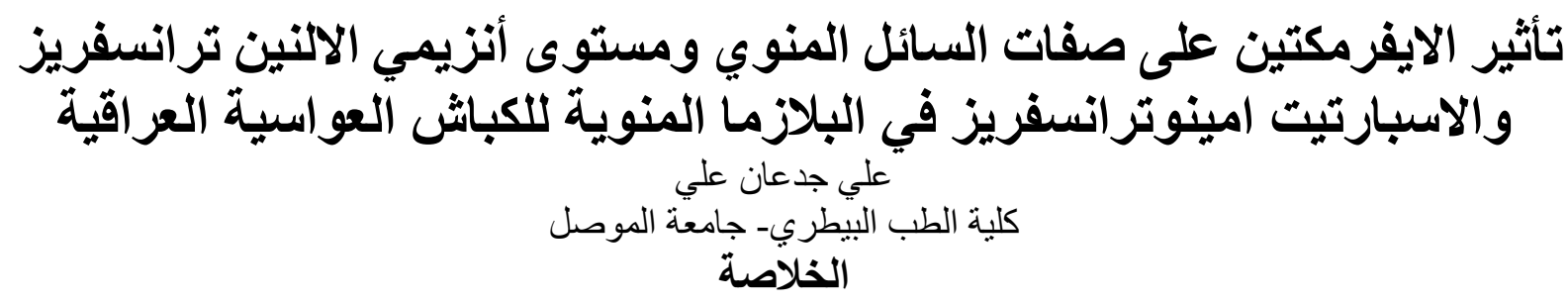

الهدف من هذه الدراسة لغرض معرفة تأثير الايفرمكتين على صفات السائل المنوي ومستوى أنزيمي

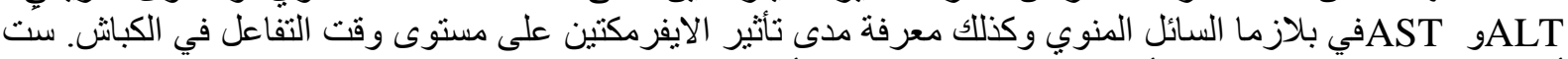

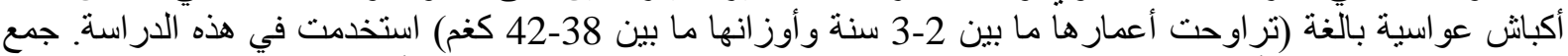

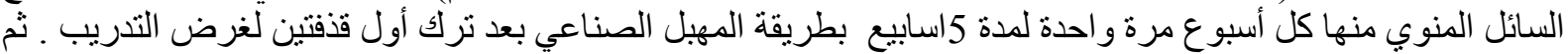

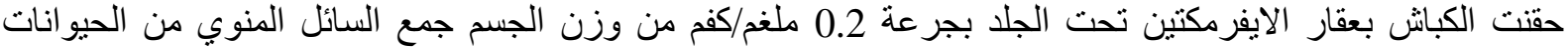

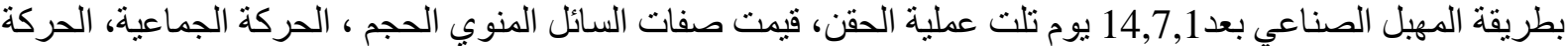

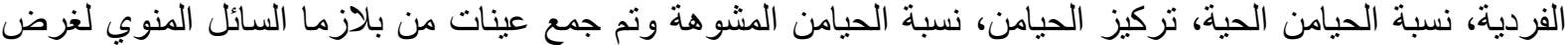

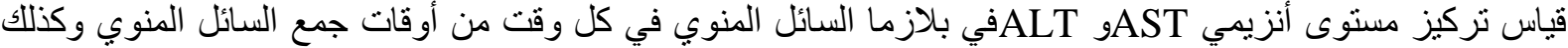

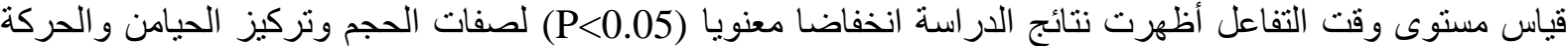

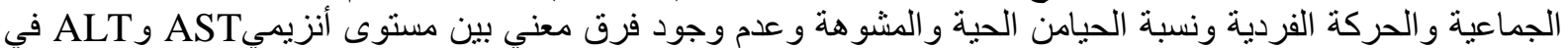

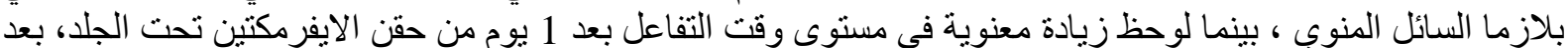

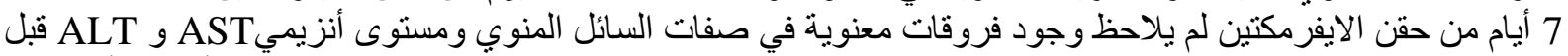

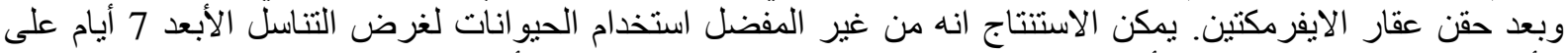

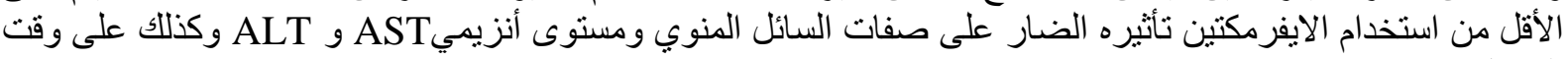




\section{Introduction}

Alanine aminotransferase (ALT), Aspartate aminotransferase (AST), has been found in mammalian tissues (1) like liver and head of sperms which consider as seminal plasma enzyme (2). The acrosomal enzymes existing at the head of sperm facilitate the penetration into ovum (3). The Transaminase activities (ALT and AST) in semen is a good indicator of semen quality because it measures sperms membrane stability (2). It was reported that there was a significant correlation between semen ALT and AST enzyme activity and sperm damage which may be occur during sperm storage and handling (4) (5).Other reports hint that estimating ALT and AST enzymes levels are useful for semen evaluation, these reports found a types of correlation between levels of these enzymes and sperm viability and founds increasing of these enzyme levels in semen sample which refers to poor quality(4),(6),(7). Ivermectin is a drug that has been used against nematodes and ectoparasites. (8), Ivermectin effect on GABA neurotransmitters causes paralysis of the parasite (9). Ivermectin can diffuse to all tissue compartments except the central nervous system after being taken orally or in other ways (10), these unique character may be interfere with some normal body function like testosterone levels, spermatogenesis and animal sexual behavior addition to its harmful effect on parasites (11).there were a little information about the effect of Ivermectin on semen quality and ALT and AST enzymes on Iraqi Awassi ram after injection. This study was carried out to establish the effect of Ivermectin in semen parameters and levels of ALT and AST enzyme in Iraqi Awassi ram.

\section{Materials and methods}

Six Iraqi Awassi ram ages between 2-3 years weighting 38 to $42 \mathrm{Kg}$ body weigh were used in this study. Animals were housed in the animal house, collage of veterinary medicine, university of Mosul. Animal were feed with hay and $1 \mathrm{Kg}$ / animal barley and water this study was carried out from 1-6-2011 to 1-7-2011. Semen collection was performed by using artificial vagina. Ivermectin, (Saudi pharmaceutical industries,
Riyadh-KSA(SPI)) at a dose of $0.2 \mathrm{mg} \mathrm{Kg}$. was used. Semen samples for calculation of semen volume were taken from Ivermectin treated rams $(\mathrm{N}=6)$ at $1,7,14$ days following treatment., light microscope was used to evaluated mass motility, individual motility, percentage of live sperm, percentage of abnormal sperm (7). Sperm concentration calculated by using spectrophotometer (9). ALT and AST level was measured using the method described by (9),(10). Seminal plasma was separated from ejaculates by centrifugation $5 \mathrm{ml}$ of diluted (in a dilution rate 1:20) semen using $\mathrm{N}$-saline solution by centrifugation at 5000 r.p.m. the supernatant was stored at $-20 C^{\circ}$ until analysis using Manovidis to determination the level of ALT and AST enzymes in diluted cell. Statistical analysis the results were expressed as means \pm SE data analyzed statistically using one way analysis of variance, Data were analyzed by using analysis of variance (ANOVA) was used to determine the differences between ejaculation before and after injection of Ivermectin. Data were analyzed using SPSS (SPSS 2003, SPSS Inc.), and $\mathrm{P}<0.05$ was consider as statistically significant.11.5,2 package 2003 (12).

\section{Results}

Effect of Ivermectin on semen parameters and enzyme level (AST,ALT) were summarized in Table1. Ejaculated semen volume after treated show significantly decrease $(p<0.05)$ after 1 day followed Ivermectin injection in comparing with its levels before injection, at the 7 days of study the volume return to normal level. There is significant decrease $(\mathrm{p}<0.05)$ in mass motility and semen individual motility after 1day followed Ivermectin injection in comparing with its level before injection. and return to its level after 7 days of injection and the end of study (14 days).sperm concentration show significant decrease $(p<0.05)$ after 1 day followed Ivermectin injection in comparing with its level before injection, And return to normal level at the 7days of study and to the end of study (14 days).the percentage of morphologically abnormal sperm show significant decrease $(p<0.05)$ in compared with its level before and after injection of 
Ivermectin, and return to its level after 7 days of injection and the end of study (14 days).AST,ALT enzyme level show no significant change in compare with its level before injection. The percentage of reaction time show significant $(p<0.05)$ increase in compare with its level before injection and return to its level, at the 7 dats after injection.

Table 1: effect of Ivermectin on semen parameters and reaction time before and after injection.

\begin{tabular}{|c|c|c|c|c|c|c|c|}
\hline $\begin{array}{c}\text { Reaction } \\
\text { time }\end{array}$ & $\begin{array}{c}\text { Abnormal } \\
\text { sperms }(\%)\end{array}$ & $\begin{array}{c}\text { Live } \\
\text { sperms }(\%)\end{array}$ & $\begin{array}{c}\text { Sperms } \\
\text { concentration } \\
\mathrm{n}(109)\end{array}$ & $\begin{array}{c}\text { Individual } \\
\text { motility } \\
(\%)\end{array}$ & $\begin{array}{c}\text { Mass } \\
\text { motility } \\
(\%)\end{array}$ & $\begin{array}{c}\text { Volume } \\
(\mathrm{ml})\end{array}$ & $\begin{array}{c}\text { Day of } \\
\text { semen } \\
\text { collection }\end{array}$ \\
\hline $\begin{array}{c}33.6 \pm 0.81 \\
\mathrm{a}\end{array}$ & $\begin{array}{c}2.5 \pm 0.54 \\
\mathrm{a}\end{array}$ & $\begin{array}{c}93.3 \pm 2.5 \\
\mathrm{a}\end{array}$ & $\begin{array}{c}1.79 \pm 0.60 \\
\mathrm{a}\end{array}$ & $\begin{array}{c}92.5 \pm 2.7 \\
\mathrm{a}\end{array}$ & $\begin{array}{c}92.0 \pm 2.4 \\
\mathrm{a}\end{array}$ & $\begin{array}{c}1.43 \pm 0.26 \\
\mathrm{a}\end{array}$ & $\begin{array}{c}2 \text { weeks } \\
\text { before } \\
\text { injection }\end{array}$ \\
\hline $\begin{array}{c}34.0 \pm 0.63 \\
\mathrm{a}\end{array}$ & $\begin{array}{c}2.33 \pm 0.51 \\
\mathrm{a}\end{array}$ & $\begin{array}{c}92.5 \pm 2.25 \\
\mathrm{a}\end{array}$ & $\begin{array}{c}1.83 \pm 0.03 \\
\mathrm{a}\end{array}$ & $\begin{array}{c}93.3 \pm 2.5 \\
\mathrm{a}\end{array}$ & $\begin{array}{c}91.6 \pm 2.5 \\
\mathrm{a}\end{array}$ & $\begin{array}{c}1.21 \pm 0.25 \\
\mathrm{a}\end{array}$ & $\begin{array}{c}1 \text { week before } \\
\text { injection }\end{array}$ \\
\hline $\begin{array}{c}57.83 \pm 0.75 \\
\mathrm{~b}\end{array}$ & $\begin{array}{c}2.83 \pm 0.40 \\
\mathrm{~b}\end{array}$ & $\begin{array}{c}91.83 \pm 2.1 \\
\mathrm{~b}\end{array}$ & $\begin{array}{c}1.67 \pm 0.01 \\
\mathrm{~b}\end{array}$ & $\begin{array}{c}86.3 \pm 2.1 \\
\mathrm{~b}\end{array}$ & $\begin{array}{c}83.3 \pm 2.5 \\
\mathrm{~b}\end{array}$ & $\begin{array}{c}0.90 \pm 0.80 \\
\mathrm{~b}\end{array}$ & $\begin{array}{c}\text { after } 1 \text { day of } \\
\text { injection }\end{array}$ \\
\hline $\begin{array}{c}34.3 \pm 0.81 \\
\mathrm{a}\end{array}$ & $\begin{array}{c}2.5 \pm 0.54 \\
\mathrm{a}\end{array}$ & $\begin{array}{c}92.5 \pm 1.04 \\
\mathrm{a}\end{array}$ & $\begin{array}{c}1.81 \pm 0.06 \\
\mathrm{a}\end{array}$ & $\begin{array}{c}91.6 \pm 2.5 \\
\mathrm{a}\end{array}$ & $\begin{array}{c}92.5 \pm 2.7 \\
\mathrm{a}\end{array}$ & $\begin{array}{c}1.43 \pm 0.25 \\
\mathrm{a}\end{array}$ & $\begin{array}{c}\text { collection } \\
\text { after } 7 \mathrm{days} \\
\text { of injection }\end{array}$ \\
\hline $\begin{array}{c}34.5 \pm 0.54 \\
\mathrm{a}\end{array}$ & $\begin{array}{c}2.6 \pm 0.51 \\
\mathrm{a}\end{array}$ & $\begin{array}{c}93.5 \pm 1.04 \\
\mathrm{a}\end{array}$ & $\begin{array}{c}1.81 \pm 0.08 \\
\mathrm{a}\end{array}$ & $\begin{array}{c}92.5 \pm 2.7 \\
\mathrm{a}\end{array}$ & $\begin{array}{c}93.3 \pm 2.5 \\
\mathrm{a}\end{array}$ & $\begin{array}{c}1.45 \pm 0.25 \\
\mathrm{a}\end{array}$ & $\begin{array}{c}\text { after } 14 \text { days } \\
\text { of injection }\end{array}$ \\
\hline
\end{tabular}

a ,b Different letters within same columns for each properties means significantly different at ( $\mathrm{p}<0.05) . \quad \mathrm{M} \pm \mathrm{SE}$

\section{Discussion}

The significant $(\mathrm{P}<0.05)$ decrease of the semen volume which found in this study is in agreement with a similar study of injection of Ivermectin causes a decrease in volume of semen (2), but disagreement with (13) which find a significant $(\mathrm{p}<0.01)$ increase of the volume. This variation may attributed to the concentration, the chemical composition, and the dosage of the drug. The semen volume is returned to the normal volume after 7 days but the collection continued until the $14^{\text {th }}$ day in order to find any effect of Ivermectin treatment on semen volume, though some other researchers found increase of semen collection after treatment of Ivermectin. In this study a significant $(\mathrm{P}<0.05)$ decrease in the concentration of semen was found, and this is in agreement with (13) who find decrease of concentration of semen after Ivermectin injection and automatically decrease of volume will lead to decrease of concentration of semen and may be the drug cause decrease the sexual behavior of ram and cause decrease of oxytocin hormone who responsible contraction of smooth muscle who find in the tests (10) and these affect cause decrease of the sperm concentration but other study (2),(14) A decrease in sperm concentration was observed in the Ivermectin treated group; and this may occur due to decrease in serum testosterone and follicle stimulating levels caused by these drugs (2). follicle stimulating hormone is necessary to increase the level of androgen binding protein production by Sertoli cells and to develop the blood-Testis barrier and other functions of the cells. Once the Sertoli function developed, Testosterone alone will maintain spermatogenesis (2). The yield of spermatozoa, lower, is increased if folliclestimulating hormone is present (2). Follicle stimulating hormone is known to increase the spermatogonia by preventing atrasia of differentiating type spermatogonia, and retrain to normal concentration after 7 days of collection similar to the concentration before treatment and the concentration does not affect after 14 days of collection. 
Decreased percentage motility was also observed in Ivermectin treated groups of the present study afterl days followed treated groups this occur may be due to the Ivermectin drug affect the sperm as chemical material and retrain to normal position after 7 days of collection as the same as after 14 days of collection this is study agreement with similar studies using Ivermectin (2) this may be due to the use of drug sub coetaneous in this method of treatment and the Ivermectin is irritant and cause pain (2) a and this may be lead to long time of ram needed for amounting time until ejaculation, and because the Ivermectin cause muscle relax ion cause the ram un able to mount other study (15) reported that the effect of treatment for motility is increase significantly and these data is disagreement with this study, this may due to sperms protection by blood testis barrier which prevent entrance of any foreign chemical material in to site of spermatogenesis (15) .The effect of this drug on morphological sperm has been shown decrease of normal sperm and an increase of defect after 1 day of treatment and this is agreement with (13) and disagreement with bucks (2),stallions(15),bulls(16) but the change of percentage of up normal sperm retrain to normal percentage after 7 days of treatment and as will as no find any change of morphology of sperm after 14 days of treatment. The reaction time measured the libido of the animal, recorded the time from the ram groom and mount using the second time for measuring (17).In this study the

\section{References}

1. Natowicz, MR. and Wang, Y.( 1996). Human serum hyaluronidase: Characterization of a clinical assay. ClinicaChemica Acta,245: 1-6.

2.Azawi, O.I., Znad M.M. and Al-Jarrah, L.H. (1990).The effect of preserving bovine spermatozoa at ambient temperature on the release of phosphatases and lactic dehydrogenases enzymes.Indian Journal of Reproduction, 11: 1-5.

3. Chauhan, M.S., Kapila R., Gandhi K.K. and Anand, S.R.( 1994). Acrosome damage and enzyme leakage of goat spermatozoa during dilution, cooling and freezing. Andrologia. 26:21-26.

4.Onakpa, M.M., Ajagbonna, O.P., Onifade, K.I., Akande, M.(2010). Effects of Diminazeneaceturate and Ivermcetin on Semen and Serum Sokoto reaction time becomes significantly higher $(\mathrm{P}<0.05)$ in the same ram after injection of Ivermectin and increase number of mounts after ejaculation in compare with its mount before injection and times recorded in control group after 1 day following Ivermectin injection this may be due to the use of drug sub coetaneous in this method of treatment and the Ivermectin is irritant(18) and cause pain (19) (20) and this may be lead to long time of ram needed for amounting until ejaculation, or may be due to that Ivermectin cause muscle relax ion and the ram became un able to mount and retrain to normal position after 7 days of treatment. The present results revealed no significant $(\mathrm{P}<0.05)$ difference in the activities of ALT, AST, in the seminal plasma after Ivermectin treated in compare with its ejaculation before treated the stability in the activities of these enzymes refer to no affected of sperm membrane in the treated group and there for no leakage of these enzyme in the seminal plasma and this means no defect in sperm membrane and no effect of Ivermectin on the levels of these enzyme .The transaminase activities (ALT_AST) in semen are good indicators of semen quality because they measure sperm membrane stability (21, and 22). Reported that one of the consequences of acrosomal damage is the leakage of enzymes from the sperm. Enzyme release has generally been recognized as an indicator of cellular injury whereby become in activated or destroyed resulting in the loss of cellular material (17).

buck.International Journal of ChemTech Research. 2(1): 738-743.

5..Schröder J, Swan G E, Barrick RA, Pulliam, J.D.(1986).Effect of Ivermcetin on the reproductive potential of breeding rams. J South African Vet Assoc.4:211-213.

6.Leaning WHD, Roncalli RA, Brokken, E.S.( 1983) The efficacy and safety evaluation of Ivermcetin: A new injectibleantiparasitic agent for cattle. Proc MSD AGVET Symposium on Recent Developments in the Control of Animal Parasites, XXII World Veterinary Congress, Perth, Australia,5:25-41.

7. Schurmeyer, T., Nieschlag, E.( 1984 ) Effect of ketoconazole and other imidazole fungicides on 
testosterone biosynthesis. ActaEndocrinol 105(2):275-80.

8.Karagiannidis, A., Varsakeli, S., Alexopoulos, C., Amarantidid, I. (2000). Seasonal variation in semen characteristics of chios and Friesian rams in Greece .small Rum ${ }^{1}$ in Res .37:125-130.

9.Tany1ldizı, S., T"urk, G., (2004). The effects of diminazeneaceturate and ceftriaxone on ram sperm. Theriogenology61, 529-535.

10.Wilkinson, C.R., Bower, L.M.,Warren, C., (1996). Measurement of hyaluronidase activity in normal human serum.J. Pharm. Biomed. Anal. 14: 707 712.

11.Knight,T.W.(1974). The effect of oxytocin and adrenaline on the semen out put of rams .J.Reprod.Fert.,39:329-336.

12-جودة،محفوظ،التحليلالإحصائي،الطبعة|الأولى،دار النشر ،عمان

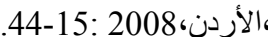

13.Tanyildizi, S. and Turk, G. (2004). The effects of diminazeneaceturate and ceftriaxone on ram sperm. Theriogenology.61(2-3): $529-535$.

14.Tanyildizi, S. and Bozkurt T. (2002). An investigation of the effects of Ivermcetin on blood serum, semen hyaluronidase activities and spermatological characteristics in sheep.Turkish Journal of Veterinary and Animal.Science. 26: 353 $-357$.

15. Janett, F., Thun, R., ryhiner, A., burger, D., Hossig, M., Hertzberg, H.( 2001) Influence of Eqvalan (Ivermcetin) on quality and freez ability of stallion semen. Theriogenology. 55: 785-792.

16.Egerton, J.R., Seward, R.L, Robin, B. (1983). Ivermcetin as an antiparasitic agent for horses. Proc MSD AGVET symposium on recent developments in the control of animal parasites, XXII World Veterinary Congress, Perth, Australia,; 49-55.

17.Azawi,O.I.,AbdulNasir,T.M. and Al-Kadoo,N.N. (2011).Stuudy on the effect of prostaglandin F2 $\alpha$ treatment on semen characteristics and enzy matic activates of Awassi rams in breeding and non breeding seasons. Research Opinions In Animal \& Veterinary Sciences, ,1(5):318-324.

18.Leaning WHD, Roncalli RA, Brokken ES.( 1983). The efficacy and safety evaluation of Ivermectin: A new injectable antiparasitic agent for cattle. Proc MSD AGVET Symposium on Recent Developments in the Control of Animal Parasites, XXII. World Veterinary Congress, Perth, Australia; 25-41.

19. Pony, S.S, Wang, C.C., Frita, I.C. (1980) .Studies on the mechanism of action of avermectin B1a, stimulating of release of gamma amino butyric acid from briansynatosomes. Neurochem.; 34: 351-358.

20.Yousef M.I and Zeitoun M.M.(1998).Bovine ovarian follicular fluids modulate the release of transaminases,acrosome reaction and motility of the rabbits sperm in vitro. Alexandria $\mathrm{j}$. Agric.Res.43, 17-26.

21. Kheradmand, A. and Babaei, H. (2006).Effect of ewe on the reaction time and semen characteristics in the ram. Iranian Journal of Veterinary Research, University of Shiraz.7, 23-26.

22.Pursel, VG., Johnson, I.A. and Gerrits, P.J. (1968).Glutamic oacetictrasaminase and lactic dehydrogenase activities of boar spermatozoa and seminal plasma.J.reprod.fertil.18, 176-177. 